Portland State University

PDXScholar

1973

\title{
Evaluating "Peer mobilization" Films as a Tool in Altering Self Concept
}

Leslie Larson

Portland State University

Mary Morton

Portland State University

Follow this and additional works at: https://pdxscholar.library.pdx.edu/open_access_etds

Part of the Social Work Commons

Let us know how access to this document benefits you.

\section{Recommended Citation}

Larson, Leslie and Morton, Mary, "Evaluating "Peer mobilization" Films as a Tool in Altering Self Concept" (1973). Dissertations and Theses. Paper 1758.

https://doi.org/10.15760/etd.1757

This Thesis is brought to you for free and open access. It has been accepted for inclusion in Dissertations and Theses by an authorized administrator of PDXScholar. Please contact us if we can make this document more accessible: pdxscholar@pdx.edu. 


\title{
EVALTATING "PEFR MOBILIZATION" FILNS
}

AS A TOOL

IN ALTERING SEL CONCEPT

\author{
by \\ Iesile Iarson \\ Mary Morton
}

\begin{abstract}
A report on a practicum submitted in partial
fulfillment of the requirements for the degree of

MASTER OF SOCIAL WORK
\end{abstract}

Portland State University
1973

APFR OVED:

Jokk Finley, MSW, Faculty Adv180\%

Thomas D. Rowland, Bd.D., Fleld Consultant 
TABIE OF CONIENTS

PAGE

ACKNOWLEDGEMFNTS.$\ldots \ldots \ldots \ldots \ldots \ldots \ldots \ldots \ldots \ldots \ldots \ldots \ldots$

INTRODUCTION................................ 1

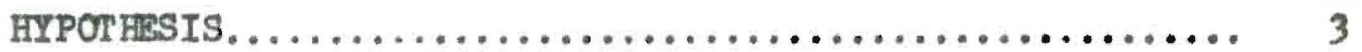

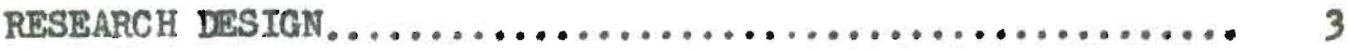

REVIEW OF THE LITERATURE.........................



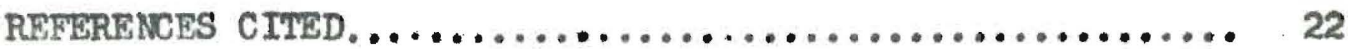

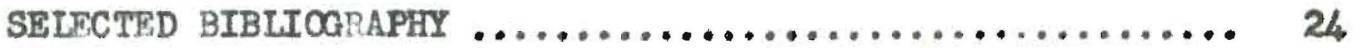

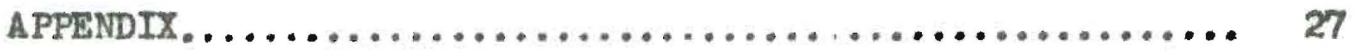


ACKWONTEDOBMENTS

We wish to acknowledge the cooperation of the perwonnel of TIgard Sohool Distrlet \# $23 \mathrm{~J}$ and the James Templeton Elementary Sehool. Special acknowledgenents should go to Mr. Robert Greemood, DIreetor of Pupl1 Personnel, and to Vh. Robert Post, Principal of James Templeton Iententary Sohool.

The eoopervtion of Me. B1II Harrold, Couneelor at James Templeton Elementary School was esøential and appreciated, as was the cooperation of the sixth grade teachers. We wigh to glve speclal thanks to these teachers, Ns. Stephanle Sachtler, Ma, Carolyn Hearings Ms. Betty Mrtin, and Mr. Harrison Bryant and to each of the studentrs who partielpated in the testing program.

In addition, wh wh to acnoriedge the contributions of our research ooventtee, Mr. Jack Finiey, Associate Professon Portiand State University Sohool of Social Work, and Dr. Quinton D. Claricson, Research Consultant, PortIand State Univeraity Sohool of Social Work, and Dr. Thomas D. Rowlend, Profeasor of Pyyohology at Qregon College of Bdusation. Assistance was also recelved from Dr. Reese Hlouge and Ma. Beverly Harsog of Oregon College of Bducation. 


\section{INTRODUCTION}

The premise that schools in general and the socla. sclence curriculum in particular can and should be incorporated in preventive mental health programs is strongly suggested through arguments ranging from clear statements of function such as "one of the four major functions of the educative process is the development of emotional well belng" ( $1, p .72)$ to more general statements that the teaching of social sclence naturally lends itself to a "sensible design for a program in self understanding that would serve preventive purposes." (2, p. 572)

The potential of films in a school based program of primary prevention has been pointed out by Wylle who cites evidence that suggests "fllms may have had a tendency to effect self-regarding attutudes" (3, p. 164) and Long who states specifleally that a preventive mental health prograin should include "examples taken from literature or P1lms." (2, p. 573)

The Peer Mobilization Program is a Pllm serles which attempts to teach about human behavior and to utilize the school setting in a preventive mental health program. MThis program is designed to...reduce management problems within the classrocm and to enhance the mental health of chlldren." (4) The film serles consists of nine short, two to six minute sixteen millimeter color sound films. Topics of the films are Conditioning, Bully, Shy, Rules, Tattiing, 
Anger, Fear, Stealing, and Daydreaming. The films aro accompanied by a manual intended for use by a teacher, principal, counselor, nurse, social worker or psychologist. The producer of the program antlolpates the films will have impact on children at three levels. At the cognitive level it is believed that children learn masic princlples of human behavior." At the affective level the program enhances "compassion and self acceptance," The inpact at the third level, called "reality" by the producer, is belleved to result in increased "emotional honesty." (4)

The authors' bellef that the school setting should be utilized in preventive mental health programs and that the Peer Mobilization Program provldes a useful model for such efforts led to the decision to evaluate the effectiveness of the fijms.

InItially, it was thought that an instrument measuring behavioral change could be used in the research. Such instruments were found to be unmanageable in our circumstances because they demanded more time of teachers than was tolerable. Additionally, the authors' theoretical orlentation regarding self concept lead to preference for a self concept scale. The reason for this preference is clearly stated by Wylle,

As is well known self concept theorlsts (phenomenological) belleve that we cannot understand and predict human behavior without knowledge of the subject's conscious perception of his environment, and of his self as he sees It in relation to the environment. $(3, p, 6)$

Consequently, it was declded that a self concept seale, the Self Goncept and Motivation Inventory, would be ut1lized."

Whereafter the Self Concept and Motivation Inventory will be 1dentifled as the SCAMIN. 
HIPOTHESIS

The following null-hypothesis was postulated. The welf concept, as measured by SCAMIN, of children who have experienced the Peer Mobilization Program is not signiflcantly different from the self concept of ch1ldren who have not experienced the program.

RESEARCH DESIGN

Selection of Research Site

Three conditions were considered as necessary in the selection of a research population.

First, It was necessary to select a school which had purchased and Intended to use the Peer voblilization Promsam. This condition may compramise the validity of the research in that the decision to purchase a mental health program Implies a concern with and awareness of mental health problems which could result in the sample population having an atypical school experience.

Secondly, It was necessary to locate a school which was sltuated geographically in such a place that accessability was not unduly restricted by travel and time problems.

Third, to be considered as a possible site for the research the school adininistration needed to demonstrate interest in research and evaluation of Its' program. This condition may also compromise the validity of the research in that wlllingness to particlpate in such research may reflect an unusual concern with mental health as well as a belief that mental heelth problems are being dealt 
with effectively. The James Templetion Elementary Sohool In TIgard, Oregor was selected as a site which met the elementary conditions described above.

\section{Selection of Research Population}

The declsion as to whleh students would comprise the research population was made by the school counselor at James Templeton Elementary School. It was his responsibility to present the Peer Mobilization Progrem in the sohool and consequently the decision as to which children would be involved in the research was assigned to him.

After 1t was decided that the research population would consist of the entire sixth grade class the experimental and control groups were selected. To avoid the sampling bias interjected by selection of students on an individual basis and for reasons of administrative convenfence It was declded that all the members of two of the four sixth grade classes would be designated experimental subfects and all the members of the two remalning classes would comprise the control group.

The selection of experimental subjects and control subjects was not done randomly. The selection process involved discusations between teachers and counselor and the major consideration was scheduling convenience.

\section{Deseription of Ressearch Population}

It is the Impression of the authors' that the school selected as the research site, the James Templeton Elementary School, does 
differ from the average or typical sohool both in awareness of mental health problems and feeling of being successful in dealing with mental health problens. These differences are speclfically reflected In the use of teaching methods suggested by Glasser and the attitude of the administration, counselors and teachers that the Peer Mobllization Program is an addition to an already successful program. James Templeton Elementary School is a modern Pacility located In a middle clasis residential area. The bullding is divided into two whing which are connected by a covered walkway.

The four sixth grade classes are housed in a complex of four rooms separated by dividers which can be opened to create one large center for group activitles. The sixth grade classrocms are furnished with chairs and tables with four to six students at each table.

It is the opinion of the school counselor that the population served by James Templeton Elementary Sohool is "solidiy middle class." This observation is supported by the following facts. In March of 1973 when 590 students were emrolled only twelve students were particlpating in the free Iunch progrem. A school secretary estimated that of the 590 students all but "about a dozen familles" lived in single family residences. An additional characteristic of the student population is the unusuel stablifty suggested by an annual student turnover rate estimated to be four per cent.

The students at James Templeton Elementary School are character1zed by the school counselor as being "sophisticated regarding psychologlcal 1ssues." For example, with the exception of new students, the ohlldren involved in this research have had four years of 
experience in "group problem solving" in the classrocm.

The teacher-student ratio for the entire school is $1-25$ and for the sixth grade it is 1-28. These ratios do not include the reading speclallst, speech therapist, counselor, librarian, music teachers, and two full time teacher aldes.

Test Instrument and Administration

The decision to use the SCAMIN was made after examination of available self concept measures and after consultation with two professors of educational psychology at Oregon College of Education. Its use was suggested on the basis of their knowledge of the test and of the fIIm serles used in the research.

The SCAMIN was developed by George M. Farrah, Norman J. Melchus, and William Reltz and was copyrighted in 1968 under the Incorporated name of Person-O-Metrics. Rellabillty of the SGAMIN is estimated by the authors as .83. A search of the literature falled to reveal evidence which would contradict this estimate.

The issue of the validity of self concept tests is considered in the review of Ilterature included in this paper.

The SCAMIN is a self concept scale which may be administered to individuals or to groups. It requires no reading on the part of the respondent and time in administering it is not a significant factor.

The test was adminiatered twice during the course of this research. Both times 1 was administered to all the research subjects, experimental and control, and both times the test items were read 
by the same person. The testing was done in the four rocm complex which houses the sixth grade students of James Jemploton Elementary Sehool.

The SCAMIN is composed of a serles of questlons prefaced by What face would you wear 1f..." The response sheets conslst of a serles of flve taces, ranging frot happy appearing to sad appenring, for each test question. Test respondents are instrueted to macik wth a penell the nose of the face whlch most nearly reflects their Peelings in reaponse to each test 1tes."

The SCAMIN produces scores on twelve different acales. In this research the aelf concept scale, the academie self seale, and the peer support soale are considered.

\section{REVINA OF THE LTMERATURE}

\section{Tovard Develoning a Working Defintition of Self Concept}

Theorlsts have been struggling whth the construset of "self" for centuries. As early as man began recording philosophle thought there have been indleatlons of the apeculations made around the unique part of man which is sopasated from his physteal belng. Translations of promsceratic writings provided the concepts of "goul" and "payche" $(5, p, 9)$ These concepta became the nuvilous for other early thinicers who developed the mind-body Idea and provided a basla for future efforts to understand the human beling. Although It is generally aceepted that the developnent of the "sele conoept" of an Individual begins whth the birth of a hunan

a sample copg of the SCAMm test response sheets is Inoluded in the appendix of this paper. 
being and continues throughout 11fe $\left(6, p_{0}, 16 ; \%\right.$ p. 575) there Is less agreanent as to the moaning of the phrase. In order to establish oriterion for the prosent study it will be necessary to consider the development of the use of the tera self concept. The interchangeable use of the terms self and self coneept needs also to be explored brieny. By constdering these two toples we will establish a working definftion for this researoh project.

\section{\#listoriea1 Dovelopnent of Self Coneopt Theorlos}

It is not the intent of this paper to provide an indepth histosleal background of self concept theortes but a brlef aumanry will be offered.

In the late 1800 's WIIIJan James, Ameriean philosopher and peychologlst, appears as the Plrst to give consideration to the self as being Iaportant to the developpent of total understanding of the peychology of man. James belleved in the separation of the "I" from the "Mg" as had been distinguished by previous thinkers, "Mg" being the self as lanown, the "maptrical ego"... and "I" being the welf as lenower, the "pure ogo." (8, p. 43, 9, p.5) An important dimension added by James" thinking was the consideration that man whas as many different aocial selves as there are distinot groups of persons about whose opinion he cares," (8, p. 46) About the same time George Herbert Moad, a social psycholog1st, was developing his theorles wich oredit Interpersonel relationships as being basio to enculturation and the development of self. (10, p. 15) At the turn of the century and for the next fow decades, while Amorican paychology was entrenched in behorloristie thinking 
and gave little thought to self or self concept, Freud in Europe was presenting his psychoanalytic theory.

Freud's theory proposed that the personality is made up of the 1d, the ego, and the super-ego. Although integral to the whole personality the three are often studied separstely. The 1d is the source of the pleasure seeking implusive behavior of man. The ego relates to reality and serves to regulate behavior toward postponment of satisfaction of instinctual drives. The super ego is often considered symonomous with the consclence and as such strives for perfection. It is Freud's construct of "ego" that approaches the definition of self concept (11, p. 186) and it was his Introduction of a "selfreferrant" which enabled other thinkers to move ahead in dealing with unconsclous material in relation to self. $(5$, p. 738)

In summarizing the effect of Freudian theory upon American psychology authors David Shakow and David Rapaport state they belleve the influence was great but that true understanding of Freudian theory has been absent. Iindzey and Aronson (J 2, p. 290) suggest that the beneflts of this influence may be in debate but the exlstence of the Influence is no longer in question. The influence of the non-phenomenal criterla on what was previousiy considered and measured as consclous and thus known to the individual has Incressed the difficulty not only in understanding the construct of self concept but also in developing accurate measurements.

As stated above, American paychologists had been deeply entrenched In the behavioristic model which concerra itself with observable data. They were, however, beginning to see phenomenon in their 
elinical work which could not be explakned by thelr 11 iting theorles. SIowiy Anerleen perchology aclmowledged and Ineorporated sone of the peychoanalytio thinking proposed by Freud.

This phenosenon 11 matrated by Ralmey in 2948 when he Plrst ut1lized the tern self concept in deseribing his clinioal. observations. Rainey deflned self concept as,

a lesmed pereeptual eystes which not only influcases bebavior but is 1 tself alternd and restructured by bohavior and unsatisfled needs and may have llttle or no relationahlp to external reallty, $(13, \mathrm{p}, \mathrm{VI})$

The development of self conespt dofInttlons, then, began wh the division of theoretieal schools upon which st is based. As has been noted the peychoanalytic theory posites a nos-phenomenal or unconolous base and can be seen at one end of the spoetruris whlle behavioristie theory with 1ts phenowenal or conselous base can be found at the opposite extrene. According to Wylle the terne self concept is most generally 11 nked to the phenomenal salf and as such 1s more eas1Iy measured. (3) AIthough 1t does seen to be true that most of the empleleal studies have been done around the phenomenal geif the theorlsts have continued to develop Idess which include non-phenonenal material.

Adler developed a theory generally know as Individual Paychology. Adler sav man as alwaye striving for perfection as reflected through othor Individuals. Salf-appraisal, according to Adlex, was a constant search for a style of 11fe eomptable wth his perception of hinself in relstion to others and to hls oulture. Self concopt Is deflned in terms of Ife style which is based upon an evaluation of seif and woctety. (1/4, p. 123) 
1 group of psychoanalyists labled "neo-Freudian" have been Influencial in adding new dimensions to the consideration of self concept. Brick From and Karen Horney, for example, both developed concepts Incorporating the effect of social influence in establishing patterns of personality.

Harry Stack Sullivan, an American psychoanalyist, talks of the personified self as that part of the self-system which is reflected in statements pertaining to the subject, "In, and as such It is a source of communicated information, as contrasted with other information about the person's selfisystem which must necessarily be inferred. What the informant can tell about his self-system is the content of the personified self. (15, p. 178) The self concept, according to Sullivan, is developed from reflected appralsals of signifloant others in the child's 11fe. (11, p. 188)

Carl Rogers, an American who has developed a cllent orlented philosophy of psychotherapy, hes a holistic approach. He sees the self or self concept (Rogers uses the terms synonomymously) as referring to the "organized, consistent, conceptual gestalt composed of perceptions of the characteristios of the "I" or "me" and the perceptions of the relationship of the "I" or "men to others and the varlous aspects of $11 f e$, together with the values attached to these perceptions." (16, p. 245)

Another who has given much consideration to self and/or self concept is Brick Brickson who talks about an integrated set of themes which establish "ogo Identity." To Erickson "ego identity" is developed through a process in which 
his sense of Identity is confirmed to some degree by the perceptions and treatments of him by other people, congruent with and based partly upon the role structure that exists in soclety. (17, p. 105)

A search of the 11terature has revealed almost as many theories of self and/or self concept as there are theorlsts. True differences In the meaning of the terms self and self concept are obfuscated by the Interchange of use made by authors and theorists. Following a comprehensive review done in 1961 Ruth Wylle states

When one reads the empirical literature pertaining to self concept theories one finds that a bewildering arrey of hypothesis, measuring instruments, and research designs has been used (and) the theorles are in many ways amblguous, imcomplete, and overlepping and no one theory has recelved a large amount of empirical exploration. (3, p. 3)

Additional work done by Coller in 1971 brings him to much the same conclusion. Coller states,

That the self Iiterature is not only vast but confusing was demonstrated in the first part of this paper, which examined highlights of self theory. $(9$, p. 64$)$

We w1Il leave 1t to other authors to continue a search for a definitive explanation of self concept. It is important for our purposes to understand there are many ways to approach the concept depending upon the theoretical beginnings as well as the focus of the research,

Don C. Charles, an educator exploring personality and development, proposes a basls for self concept theory which is acceptable for use In this research

While the self concept is unique and personal, it derlves from social experience. A person sees himself'as a success or a failure only in relation to his experience with others, or in the way those experlences have been interpreted for him. (18, p. 71) 
Peer and S1gniflcant Other Influence in the Development of Self Concept

Arthur Combs, a proponent of a humanistic approach which incorp-

orates some concepts from non-phenominal theory as well as behavioristic

theory, in an article entitled Mlumanizing Education: The Person

In the Process," summarizes the importance of interaction within

a school setting.

Students do not park thelr self concepts at the door, they bring them right on into class with them. What we do with these students, even when we are teaching math, or sclence, geography, music or physical education is also teaching them who they are and what they are, for it is people we teach, not just subject matter. We are affecting people's concepts of themselves positively or negatively or not at all in every contact we have with them. Whats more this happens whether we know it or not. ( 19 pp. 80-81)

In discussing the classroom as a logicel place for preventive

mental health, Charles states,

Even children in the lower grades can grasp the 1deas of why people feel as they do, and why certain bebaviors can be expected in fear, anger, frustration, and the like. They can learn in class about healthy and unhealthy ways of expressing emotion, and can even help and support one another in learninf to understand, control, and channel their enotions. (18, p. 85)

Sears and Sherman argue that children of ages five to twelve or thirteen spend a large proportion of their waking hours in school, and there develop under guidance their reasoning and Inquiry sklils, find their place and their influence in a group of children their own age, and derelop their orm senses of competence in relation to real work. $(20, p .2)$ Charles stesses the importance of peer support...

by late childhood most of the rules by whioh ehfldren live are formulated by peers with little reference to 
perents and teachers...children are intensly concerned with having the mright" perceptiona-right being that of the peer group. (28, p. 66)

Thuag, we see the Importance of baing avare of the needs of chlldren, the offect of pers and signifleant other influence, and the ut1liation of the wohool setting as a natural place for the enhancement of aelf concept.

\section{Altering Self Concert}

It becones elear that in the current perlod of peychologteal. history almost every stetement about self or welf concapt Includes some mention of intaraction, whether it be Individual, eg, peer, or social, eg, fami.1y, as being important to the develogment of and essential to change in a person's perception of himself. Statements wach as,

Any discusalon of aelf-development returns to a discusalon of the growth of personality within the bone and in the educational framework. A chlld's conpldenoe, inaginatlon, and sense of well-being develops slowly and gradually every day that be 11ves. If he is approved of he galns confldence, (7., .575$)$

and from Jersild the following

Each person's self is something individual, yet it has a soclal origin. This fact bss important mesnings for educatIon because many of the strongest soclal influences are brought to bear upon the ch1ld by way of his experiences at sohool., (6, p. 11)

omphasise the importance of interpersonal transactions in the developuent of self coneegit.

Jeratld goes on to discuss changlng self concept by saying,

The self is acquired. It is not readiry made. It develops as a person, wth all his inborn ablilties and tendencles 
and all that is inherent in his meke-up, meets up with the experlences of 1ife. (6, p. 16) The self is both constant and changeable. (6, p. 9) Thus, while the self is a continuously growing and changing phenomenon, it is also, paradoxically strongly geared to prevent growth and ohange. A person seeks to preserve his selfhood even though it is based on false premises. (6, p. 19)

Other authors develop the Idea thus,

A person needs to think well of himself and be in falriy continuous rewarding relationship with life and people in order to avold the stress of lowered self-esteen., (7, p. 574)

and

The amall child looses self-esteem when he loses love and attains it when he regains love. That is what makes children educable. Bvery feeling of gullt lowers selfesteem every fulfiliment of 1 deals ralses 1t. (2l, p. 4I)

For phenomenologists the problem of changing behavior is really one of assisting the chlld to percelve things differently, of enabling him to see the possiblilty of more effective relationships. (11, p.188) Rogers utilizes this concept and observes that during psychotherapy a cllent's self concept generally changes, the way he perceives himself becomes different. (16 p. 245)

Wylle summarlzes effects of fifteen experiments where success or fallure was a controlled variable stating

under certain clreumstances the subjects will change their self-evaluations after experimentally induced success or fallure. There is some evidence that changes in selfrating upward after success are more frequent than are changes dowmard after fallure. (3, p. 198)

Research such as this produces results valuable to those who work with chlldren and such results have partlevlar signifleance for this research. Of greater ignifleance for this research is Wylle's statement that "A person's presented level of self-respect 
Is of great importance in predicting his behavior." (3, p. 184)

There is relevance then in measuring self concept while the subjects are involved in a therapeutic experience such as established for this study.

\section{Mathods of Maasuring Self Concept}

Despite the continued emphasis in the literature on the self concept as an important factor in the study of human behavior and experlenoe, there has been astonishingly Iittle experimental work reported. A probable reason for the dearth of studies is the difficulty in developing effective measurement tochniques that con give rich and objective information about the individual's self concept. (14. p. 491)

As with the development of the definition of self concept

the frames of reference of measuring self concept range from the objective or mechanistic point of view to the subjective or perceptual point of view. Dinkmeyer examines the differences,

When we use the objective approach sometimes also referred to as stimulus-response psychology, we attempt to explain behavior in terms of set stimuli to which the individual appears to be reacting. This has been a fairly useful means of obtaining information about "average" or "nownal" behavior and many significant statistical studies have been built upon this approach. The subjective approach starts with the assumption that behavior is purposeful and caused and that people behave as they do because of the way things seem to them, and not soley because of set external stimull. (II, p. 18I)

Testing of self concept continues to be complicated by the

different approaches taken by theorlsts. Ruth Wylle suggests,

We would like to assume that the subject's self-report responses are determined by his phenomenal fleld. However, we know that it would be nalve to take this for granted, aince it is obrious that such responses may also be influenced by (a) subjects Intent to select what he wishes to reverl to the experimenter; (b) subjects intent to say that he has attitudes or perceptions which he does not have; 
(c) subjects response habits, particularly those involving Introspection and the use of language; (a) a host of situational and methodological factors which may not only induce variations in (a), (b), and (c), but may exert other more superficial influences in the responses obtained. (3. p. 24)

Llebert and Spiegler resolve the dilerme thus, "Direct selfreports are useful in many cireumstances both conceptually and as real predictors of behavior.", and Dement as quoted by them

We accept...these concepts without qualification because long experience has shown over and over that they do correlate with observable events in the real world... rigorous proof appears hardly necessary in view of the obrlous utility of assuming that his feelings are real. (16, p. 37)

In view of the problems inherent in any effort to measure self concept and change in self concept the author's belleve that the SCAMIN offers a self concept scale which is as valld as any presently avallable.

$$
\text { DISCUSSION OF DATA }
$$

\section{Test Scales}

This study was conducted to evaluate the effectiveness of the Peer Mobilization IIIm serles as a preventive mental health tool when used with elementary school chlldren at the sixth grade level. A test which generates a self concept scale, the SCAMIN, was employed to measure the effects of the Peer Mobilization 217m serles. In addition to self concept two other scales generated by the SCAMIN were considered, These are "Peers and siblings as source of support climate" and the "Academic self" scales. 
The manual for interpretation of the SCAMIN defines these

scales thus:

SELP CONCEPT is made up of "role expectations"-the positive acceptance of the aspirations and denands that the student thinks others-signiflcant otherg-expect of him, and self adequacy-the positive regard with which a student views his present and future probabllitles of success.

PEFRS AND SIBIINGS AS SOURCE GF SUPPORT CLIMATE - Peers and siblings are included in the author's definition of signifleant others as-parents, siblings, peers, teachers, and sometimes, nolghbors, adult relatives and friends of the family which have an impact on the child's 11fe. The student views his signifleant others as models for his behavior. They confer the approval and disapproval that seems to matter. SIgnlfleant others tell the student in many ways what he is and how be is expeoted to act. They establish a climate which threatens or supports.

THE ACADBMTC SELF Implies the standard of an ldeal self which is included with signifleant others. Some expectations, standards, needs, and fears become intenmalized so that their source of support seems to be part of the consclence, superwego, or self.

The authors of this peper assume that the occurrence of signiflcant change in these scales among students who experlenced the Peer Mobilization 117 serles would provide reason for rejecting the mull-hypothesis stated earlier in this paper.

Subjects

The sucjects of this research consisted of an experimental and control group of sixth grade students. The total population of the Pour classrooms involved in the research was one hundred six students. Forty-seven of the experimental subjects were acininistered the pretest and fortymone of them were administered the post-test. Fifty members of the control group were adninistered the pre-test and Porty-one were present when the post-test was adninistered. The 1095 
of subjeots is not belleved to compromlte the findings. Subjects wore lost because of absence from school due to 1.11 iness and because of sehool activities whlch renoved them from the clasarocm at the time of the testing. Students were not avare of the time of testing unt1l after their arrival at school on the day teating was seheduled.

\section{Seoring}

The subject is test response theets were seored manually. Randor rechecking of ten per ennt of the response sheots revealed no errors In seoring. A computer progran genorating a t test of the - Ignifleance of the differences between means was used in evaluating the data.

\section{Results}

Differences between means were established by subtracting post-P1Im test score means from pre-rilm test soore means. The I scores were computed for the differences between the control group and the experimental group means. A te score of 1.99, S0d, p<.05 wes deternined.

Whin these parameters no signifleant differenees wore found. However, two I scores, that of the Self Concept seale and the Peers and Slblinge as Source of Support Glimate seele, approached the .05 level of signteleance. The $t$ score for the Self Concept seale was 1.814 and the $\mathrm{t}$ seore for the Peers and Slblings as Source of Support Climate soale was 1.945.

The author"s wh to note that $t$ teats for two of the SCAMIN seales did reflect a statistieally signifloant change. These 
scales were Aogdemle Yotivation, $t=1.988$, and Aohlevement Investments $t=2.085$. The $t$ values for all of the scAMIn seales are reported In the summary of statistles included in the appendix of this paper.

\section{Conclusions}

The results of this research do not refoct the null-hypotheses prevlousiy stated in this paper. No signifleant change occurred in the self coneept of the chilaren who experlenced the Peer Mobilization Plin serles.

In addition to the conditlon previously ldentifled as restrictIng the vallatty of the results the authors feel there are additlonal Pactors wich must be considered.

Plrat, the post-test was administered one wek after the completIon of the PIIm series and the entire IIIm serles ws presented In - four month perlod. Since aelf concept develops and changes progressIvely a longer time frame for presenting the flins and a longer period between completion of the series and post-testing night have resulted In different pindings.

An additional fact which must be considered is that chlidren In the alxth grade are at the upper age linit of atudents for wilch the fliss are designed. Th1s fact may account for the lack of enthusiess whlch was reported by the school counselor as characteristle of student response to the rilns.

It is belleved by the authors that dePlnitive statement about the effectiveness of the Peer Mobilization flin serles cannot be sade unt1I sindiar research is conducted with subjects wo are of 
varying ages and of diverse soclo-oconomic levels. Additionally, It seems advisable to conduct this research in a school that has not previously emphasized preventive mental health programs because the school experience of the subjects of this research has been designed to enhance their emotional as woll as cognitive capacities. It seems possible that these students have approached the upper limit of their ability. to benefit from school based preventive mental. health efforts.

The factors discussed above lead the authors to make two recommendations for the future use of the Peer Mobilization program at the James Templeton Elementary School. The first is that the program be used with students at grade levels three, four, and Plve. The second is that the films be presented at regular time intervals durling the course of an entire academlc year. It is believed that implimentation of these recommendations would maximize the effectIveness of the Peer Mobllization program. 
REFERENCES CITED

1. Shaloek, Henry D. Kotion Plctures as Test Stimuli-An Applleation of New Media to the Prevention of Complex Behavior. Momnouth, Oregon: Oregon State System of Higher Bducation, HDEA-VIIA971, R-33, 31, Dec. 196/n 477p., CSG-7-47-000-186.

2. Long, Barbara EII1s. MA Model for Elementary School Bohavioral Selence As an Agent of Primary Prevention," American Perchologist. XXV No. 6 (June, 1970).

3. Wylle, Ruth C. The Self Concept: A Critical Surver of Pertinent Research Iiterature. IincoIn: University of Nebraska Press, 1961.

4. Rovland, Thomes. Peer Mobllization Program. Brochure by Peer Mo Product1ons, P.0. Box 306, Monmouth, Oregon.

5. Borgatta, Bdgar F., and Iambert, W1IIlam W. Handbook of Personallty Theory and Research. Chleagos Rand Nollilly, 1968.

6. Jersild, Arthur T. In Search of Self: An Exploration of the Role of the School In Promoting Self Understanding. Now York: Bureau of Publications, Teachers College, 1952.

7. English, Oliver Spurgeon, and Pearson, Gerald. Emotlonal Problems of Living: Avolalng the Neurotic Pattern. New Tork: W.W. Norton \& Company, Inc., 1945.

8. Allport, G. (ed.). Parchology: The Brlefer Course. New Iork: Harper \& Row, 1961.

9. Coller, Alen P. The Assessment of Self-Concepts in Barly Chlldhood Education. rev. ed. Washington, D.C.: National Center for Bducational Communication, Division of Information Resources, Oeflee of Chlld Development DFISW, 1971.

10. Goodman, Mary Elion. The Indiv1dual and Culture. Homewood, IIIInols s The Dorsey Press, 1967.

11. Dinkmeyer, Don C. Chlid Develoment The Bmerging Self. Bnglewood. C11ffa, Now Jereey: Prentlce Hil1, Ine., 1965.

12. Lindzey, Gardner, and Aronson, E. Handbook of Soclal Psychologr. 2d ed., V. 3. Reading, Nassachusetts: Adison-Wesley, 1969.

13. Raimey, Victor Charles. The Self-Concept As a Ructor in Counseling and Personality Organization. Onlo State University Office of Educational Services, 1971. 
14. Lndzey, Gardner, and Hal1, Calvin S. Theorles of Personality:

primary Sources and Research. Nov York: John Wiley \& Sons, Ine., 1968.

15. Sullivan, Harry Stack. The Pavehistrele Intervier. Now Iork: W. W. Norton \& Co., Lne., 1970.

16. Lisbert, Robert $M_{*}$, and Spleglex, Moheel D. Perconallty and Introduction to Theory and Research. Howewood, IIIInols: The Dorsey Press, 1970.

17. Sanford, Mevitt. Iganes In Perwonallty Theory. San PraneIseo: Jossey-Bిoss, Ine., 1970.

18. Charles, Don C. Prycholosy of the Child in the Classarocm. Now Yorks Mekilian 60., 196.

19. Combs, Arthur W, "himaniaIng Eduoations The Person in the Process," llimaniaing Bducetion: The Persion in the Process. Ad. Robert Leeper. Washington, D.C.: Association for Supervision \&

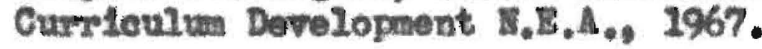

20. Sears, Faullne S, and Shermen, Vivian S. In Pursult of Self-Brteem. Belwont, Californtas Wadsworth Publiontng, 1964.

21. Fenichel, Otto. The Parchoanalytio Theory of Neurosis. New York: W. W. Morton \& Co., 1945. 


\section{SEIECTED BIBLIOGRAPHY}

Adamson, W11liam C. "A School Mental. Health Program: Development and Design," Community Mental Heelth Journal, IV, No. 6 (December, 1968).

Allport, G. (ed.). Paychology: The Briefer Course. New York: Harper \& Row, 1961.

Borgatta, Edgar F., and Iambert, W11llam W. Handbook of Personality Theory and Research. Chleago: Rand Melvilly, 1968.

Caplan, G. (ed.). Prevention of Mental Disorders In Children. New Iork: Basic Books, 1961.

Charles, Don C. Parchology of the Child in the Classroom. Now York: Mekilian Co., 1964.

Collex, Alan P. The Assessment of Self-Goncepts In Early Childhood Education. rev. ed. Washington, D.C. National Center for Educational Communieation, Division of Information Resources, offlee of Chlld Development DHIW, 1971.

Coller, Allen R., and Guthrie, P. D. Self Concept Moesures : An Amotated Blbliorraphy. Princeton, New Jersey: Educational Testing Service, 1971.

Combs, Arthur W., Whumanizling Bducation: The Person in the Process, " Himaniging Education: The Person in the Process. ed. Robert Leeper, Washington, D.C.: Association for Superviston \& Curriculum Development N.E.A., 1967.

Dinkmeyer, Don C., Child Development The Bmerging Self. Englewood Cliffa, New Jersey: Frentice Ha11, Ine., 1965.

English, Oiver Spurgeon, and Finch, Stuart $M$. Introduction to Parchiatry. New York: W.W. Norton \& Co., 1964.

English, Oliver Spuxgeon, and Person, Gerald. Pnotional Problems of Hiving: Arolaling the Nerrotic Pattern. New Iork: W.W. Worton \& Co.9 1945.

Fenichel, Otto. The Psychoanalvtic Theory of Neuros1s, New York: W. W. Norton \& Co., 1945. 
Goodman, Mary EIlen. The Individual and Culture. Homewood, IIIInolss The Dorsey Press, 1967.

Guardo, Carol J., and Bohan, Janis Beebe. "Development of a Sense of Self Identity in Children," Child Development. XIII, No, 6 (December, 1971).

Hamachex, Don E. (ed.). The Self In Growth, Teaching and Iearning. Englewood Cllff, New Jersey: Prentlce-HaII, Inc., 1965.

Jeralld, Arthur T. In Sarch of Self An Exploration of the Role of the School in Promoting Self Understanding. New Tork: Bureau of Publieations, Teachers College, 1952.

Liebert, Robert M., and Splegler, Michael D. Personality and Introduction to Theory and Research. Homewood, IIIInols : The Dorsey Press, 1970.

Indzey, Gardner, and Aronson, E. Handbook of Soc1al Psychology. 2d ed., V. 3. Reading, Masschusetts s Adison-Wesley, 1969.

Lindzey, Gardner, and Hall, Calvin S. Theorles of Personality: Primary Sources and Research. New York: John Wiley \& Sons, Ine., 1968.

Long, Barbara Ellis. "A Model for Elementary School Behavioral Sclence As an Agent of Primary Prevent1on," American Paycholog1st, XXVV No. 6 (June, 1970).

Plerson, Jeanne. "Student Opinion Toward Team TeachIng, " Gallfornia Journal of Educational Research, XXII No. 4 (September, 1971).

Pollack, Otto, and Collaborators. Social Service and Psychotherapy for Children. New York: Russell Sage Foundation, 1952.

Raimey, Victor Charles. The Self-Concept as a Fector in Counseling and Personality Orgenization. Cilo State University: Offlee of Educatlonal Services, 1971.

Roen, Sheldon R. "Relevance of Teaching Chlldren about Behavior," American Journal of Orthopsychiatry, XI No. 2 (Narch 1970).

Rowland, Thanas. Peer Moblilization Progran. Brochure by Peer No Productions, P. 0. Box 306, Monmouth, Oregon.

Sanford, Nevitt. Issues In Personallty Theory. San Francisco: Jossey-Boss, Inc.. 1970 .

Sears, Pauline S., and Sherman, Vivian S. In Pursuit of Self-Esteem. Belmont, California: Wadsworth Publishing, 1964.

Shalock, Henry D. Motion Plotures as Test Stimul1-An Application of Nev Media to the Prevention of Complex Bohavior. Monmouth, Orogon: Oregon State System of Higher Education, HDEA-VIIA971, R-33, 31, Dec. 1964, 477p., OEG-7-47-000-186. 
Stlekney, Stonewal1 B. "Schools Are Our Community Mental Health Centers," American Journal of Psychlatyr, CxxIV No. 10 (Apri1, 1968).

Sullivan, Harry Stack. The Psychlatrle Interviex. Neu York: W. W. Norton \& Co., Ine., 1970.

Wylle, Ruth C. The Self Concept: $\$$ Critlcal Survey of Pertinent Research Ifterature. IncoIn: University of Nebreska Press, 1961. 


\section{APPENDIX}

\section{Summary of Statistios}

Column A: Mean differences of control aubject's SCAMIN, Pre-PIIm minus post $111 \mathrm{~m}$

Colum B: Mean differences of experimental subject's SCAMIN scores

Colum C: Standard deviations



\begin{tabular}{rrrll} 
& \multicolumn{1}{l}{$\mathrm{A}$} & $\mathrm{B}$ & $\mathrm{C}$ & $\mathrm{D}$ \\
1 & 0.853 & 2.390 & 5.1923 & -1.339 \\
2 & -0.975 & 1.780 & 5.9833 & -2.085 \\
3 & -1.780 & 0.682 & 6.1986 & -1.799 \\
4 & -0.585 & 0.951 & 4.7590 & -1.461 \\
5 & 0.195 & 4.195 & 9.1069 & -1.988 \\
6 & -2.243 & 1.609 & 9.6185 & -1.814 \\
7 & -0.390 & 0.195 & 2.9962 & -0.884 \\
8 & 0.219 & 0.146 & 2.4498 & 0.135 \\
9 & -0.024 & 1.073 & 2.5538 & -1.945 \\
10 & 0.731 & -1.170 & 7.4244 & 1.160 \\
11 & -0.536 & 0.000 & 2.8639 & -0.848 \\
12 & 0.365 & 0.658 & 3.1794 & -0.416
\end{tabular}

Whis key identifles the SCAMIN scales for which data is presented above.

Row 1. Achlevement Needs

Row 2. Achlevement Investment

Row 3. Role Expectations

Row 4. Self Adequacy

Row 5. Motivation

Row 6. Self Concept

Row 7. Parents as Source of Support Climate

Row 8. Teachera as Source of Support Climate

Row 9. Peers and S1blings as Source of Support Climate

Row 10. Academic Self

Row 11. Academic Activity Climate

Row 12. School Support Climate 


\section{What Face Would You Mear?}

\section{Sample:}

DARKEN A NOSE

ON IHE FACE YOU CHOOSE.

$b \sqrt{a}\left[\begin{array}{l}b \\ b\end{array}\right.$

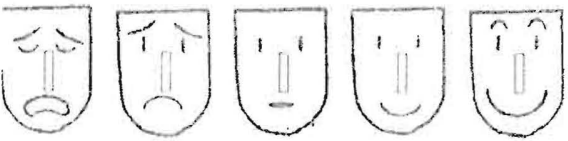

$6\left[\begin{array}{l}1 \\ 0\end{array}\right]\left[\begin{array}{l}1 \\ b\end{array}\right]$

$6 \sqrt[1]{6}\left[\begin{array}{l}1 \\ 0\end{array}\right]$

$a$
$\theta$$\left[\begin{array}{l}1 \\ 0\end{array}\right]\left[\begin{array}{l}\hat{i} \\ 0\end{array}\right.$

$67\left[\begin{array}{l}1 \\ 6\end{array}\right]\left[\begin{array}{l}1 \\ 0\end{array}\right]$

$(a)\left[\begin{array}{l}1 \\ b\end{array}\right]\left[\begin{array}{l}1 \\ 0\end{array}\right]\left[\begin{array}{l}1 \\ 1\end{array}\right]$

$60\left[\begin{array}{l}1 \\ 0\end{array}\right]\left[\begin{array}{l}1 \\ 0\end{array}\right.$

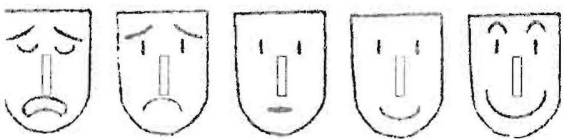

$\Leftrightarrow\left[\begin{array}{l}1 \\ b\end{array}\left[\begin{array}{l}n \\ b\end{array}\right.\right.$

$\theta\left[\begin{array}{l}1 \\ 6\end{array}\right]\left[\begin{array}{l}1 \\ 0\end{array}\right]\left[\begin{array}{l}1 \\ 0\end{array}\right]$

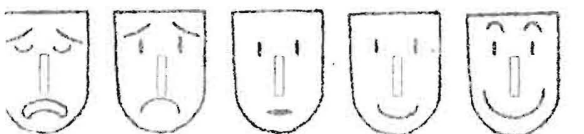

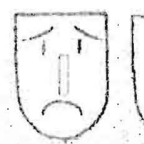

1
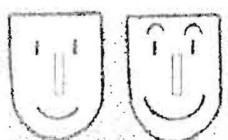

PENCIL

ONLY.

13
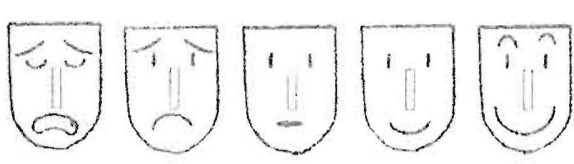

14

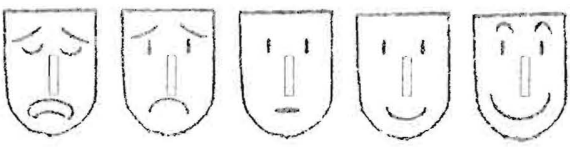

15

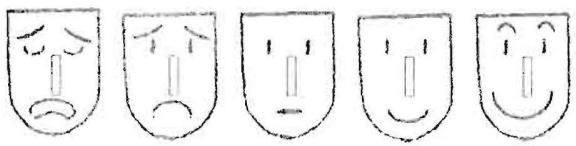

16

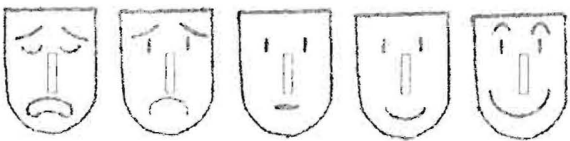

17

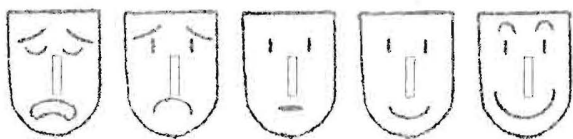

18



18

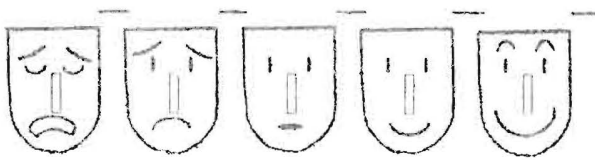

20

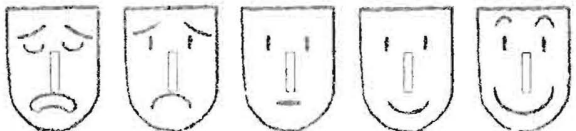

21

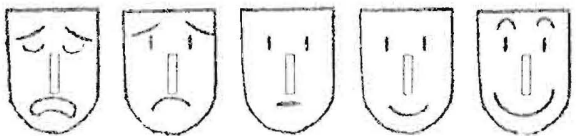

22

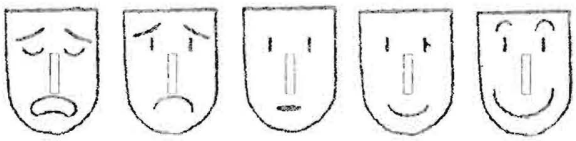

23

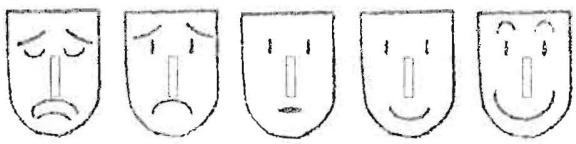



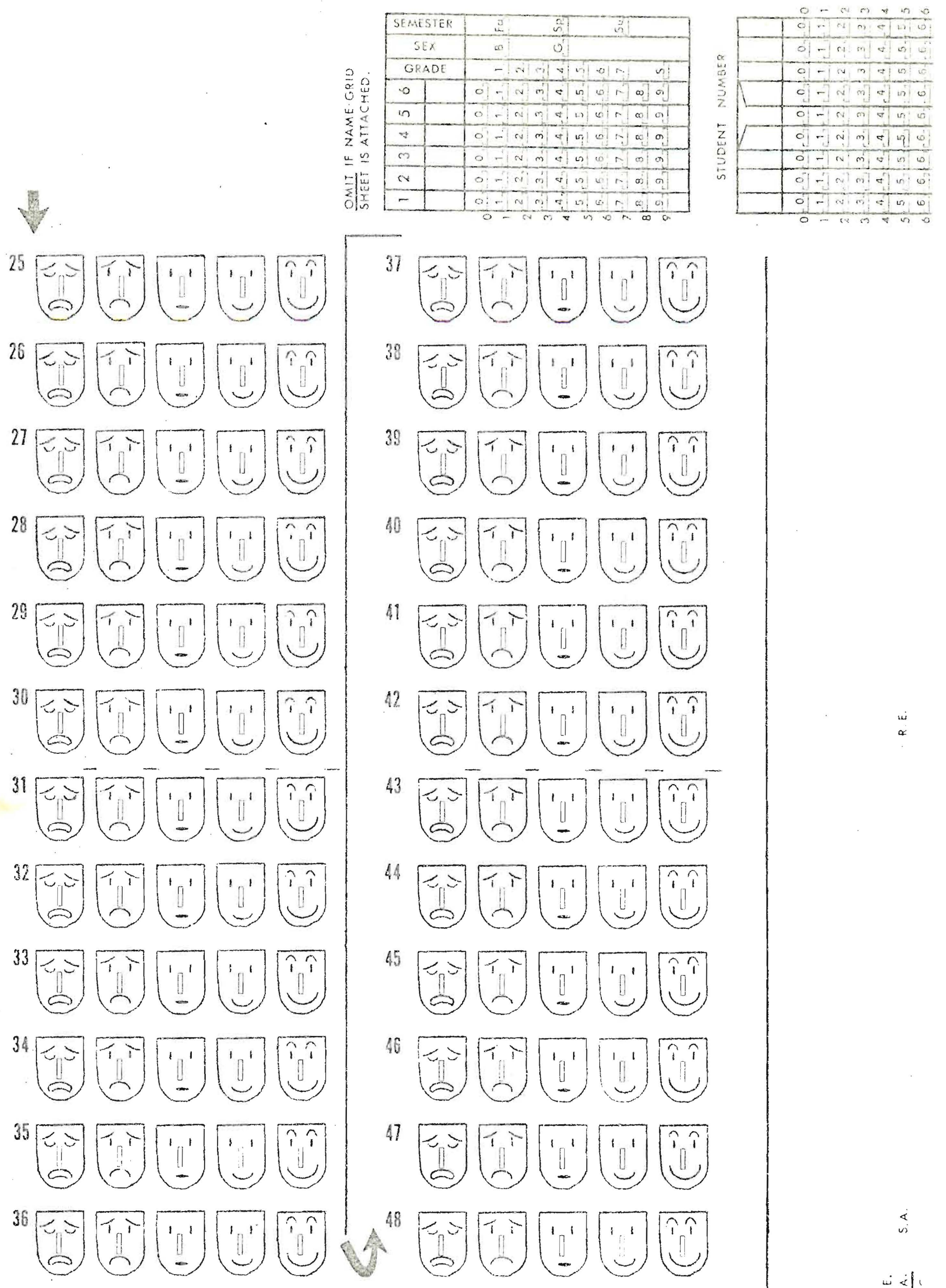